\title{
Health at the dawn of development: the thought of Abraham Horwitz
}

\author{
Fernando A. Pires-Alves \\ Researcher, Casa de Oswaldo Cruz/Fiocruz. \\ Av. Brasil, 4365, sala 416a \\ 21040-900 - Rio de Janeiro - RJ - Brazil \\ fapires@coc.fiocruz.br
}

\section{Marcos Chor Maio}

Researcher, Casa de Oswaldo Cruz/Fiocruz; professor, Programa de Pós-graduação em História das Ciências e da Saúde/Fiocruz. Av. Brasil, 4365, sala 400

21040-900 - Rio de Janeiro - RJ - Brazil

maio@coc.fiocruz.br

Received for publication in July 2013.

Approved for publication in January 2014.

Translated by Diane Grosklaus Whitty.
PIRES-ALVES, Fernando A.; MAIO, Marcos Chor. Health at the dawn of development: the thought of Abraham Horwitz. História, Ciências, Health Manguinhos, v.22, n.1, jan.-mar. 2015. Available at: http://www.scielo.br/hcsm.

\section{Abstract}

The article explores the ideas of Pan American Health Organization director Abraham Horwitz on the relations between health and development at the time the Alliance for Progress was established, in 1961. Taking development discourse as a public philosophy of international cooperation, the discussion centers on how Horwitz worked to mediate between health and development. Horwitz endeavored to establish arguments that highlighted the importance of social policy, especially in health; he also strove to reach different audiences and drew connections between elements like health, illness, and labor productivity, without ignoring the humanistic considerations so dear to the public health tradition.

Keywords: history of health policy; development and health; international health; history of the Pan American Health Organization. 
$\mathrm{T}$ his article examines how Abraham Horwitz, ${ }^{1}$ in his capacity as director of the Pan American

Health Organization (PAHO), perceived relations between health and development during the process that culminated in the Special Meeting of the Inter-American Economic and Social Council of the Organization of American States (OAS) in 1961, often called the Punta del Este Conference. It was this meeting that established the Alliance for Progress, a program of economic and social assistance for Latin America proposed and led by the United States. The same meeting, which defined the terms of inter-American cooperation at the very outset of the decades of "development," also approved the Alliance's Ten-Year Public Health Plan. Within the context of this notable conjuncture, the present article explores the enunciations that helped make PAHO's programmatic agenda relevant to development discourse and that concomitantly helped shape the development agenda itself, at a time when social policies and matters of health were brought to the fore in inter-American diplomacy. ${ }^{2}$

The article is divided into four parts: the nature and role of multilateral organizations in policymaking; development as a public philosophy of international cooperation during the period in question; the tendencies of the diplomatic agenda and of inter-American cooperation from the turn of the 1950s to the 1960s; and, lastly, the PAHO director's formulations regarding the relations between health and development.

As we will see in the articles and texts analyzed in these pages, Abraham Horwitz devised a way to mediate selectively between health and development, highlighting themes and adopting approaches that befit the broader context of development at that inter-American conjuncture and that were also designed to guarantee PAHO a prominent role as a specialized organization and as an arena of programmatic and technical consensus, where Horwitz's organization would be able to enjoy greater autonomy. Producing enunciations in tune with the interests of the organization he headed, Horwitz selected and relied on authors and arguments from diverse and sometimes conflicting sources while still keeping to the more overall terms of the day's thriving discourse of development.

\section{International organizations: relevant actors and arenas of negotiation}

The present text considers international, governmental, multilateral organizations to be relevant actors and arenas of negotiation at one and the same time. As actors, they can make choices and produce realities, whether by engendering and disseminating values and norms or through direct institutional initiative. This also means these organizations operate according to the worldviews and interests of their bureaucracies; thus, they cannot be regarded merely as places where meanings and interests that arise outside their institutional figurations and histories find echo or space (Maio et al., 2010, p.1274).

For example, this accounts for how the United Nations Educational, Scientific, and Cultural Organization (UNESCO) was able to respond to interests and expectations expressed within the sphere of influence of its Natural Sciences Sector in the 1960s and 1970s; it stimulated the creation of national bureaucracies in almost a hundred countries in the form of national research councils devoted to scientific and technological development, often times where this type of activity had been practically nonexistent before (Finnemore, 1996, chap.2). 
International organizations are also arenas, given that outlooks and interests from a broad gamut of origins, governmental or not, coexist and compete at different levels within these structures. The interests of their internal bureaucracies may also be expressed within this same competitive environment, thereby necessitating the adoption of strategies to convince others and to garner legitimacy (Maio et al., 2010, p.1274). Playing this twofold role of relevant actor and arena of negotiation, an intergovernmental organization can be seen as somewhat akin to a nation-state, and this holds true when it comes to examining processes of public policy formulation and implementation. ${ }^{3}$

In this regard, Margaret Weir (1992, p.188-192) argues that the process of designing and enforcing social policy within a given institutional context entails a certain merging of public philosophy, programmatic ideas, and administrative means. On the first and more general level, Weir understands "public philosophy" as enunciations concerning values and principles that refer to the moral or ethical foundations, meaning, and legitimacy of a given initiative. On an intermediary level, programmatic ideas are those that lend themselves more readily to practicable actions within a given sphere or realm of activities; in the case at hand, this would involve the formulation of an agenda and of a recipe for means and ways of acting, thereby constituting a prime environment for the authorized discourse of experts. Lastly, administrative means involve the mobilization of an institution's operational resources to implement a given policy. A policy proposal stands a better chance of success when the relations between these three components are hardier or denser. ${ }^{4}$

This type of approach suggests that a study of public policy formulation and implementation can be based on a design with three interconnected analytical levels: the more general level of representations; the level of intermediary or sectoral formulations, where features of a programmatic nature have greater relevance; and the level of features related to policy implementation per se, where operational aspects stand out. Within this analytical design, special attention must be paid to mediations between these levels (levels, it should be noted, that reflect distinctions posited solely for the purposes of analysis).

We believe that adopting a similar analytical framework may be particularly useful in guiding a historical investigation of policy emergence and implementation by an international organization like PAHO. Combining an analysis of elements that have to do with, on the one hand, the more general realm of principles and values and, on the other, the realm of specialized knowledge and technique leads us to suggest that functional international organizations ${ }^{5}$ constitute an environment especially propitious to the examination of relations between these spheres - that is, to an examination of mediation between general values, programmatic agendas, and concrete methods of operation.

\section{Development as a public philosophy of inter-American cooperation in health}

In the inter-American context, the public philosophy of international health from 1949 to 1979 was development. ${ }^{6}$ A few examples from the field of critical studies of development will suffice to clarify the concept of development for our purposes. In these studies, development is regarded as a social construct, firmly anchored in Western cultural traditions and potentially displaying: (1) elements of transcendence, in that development refers both to antiquity and 
to modernity, that is, to a long-running collective Western experience, which encompasses its colonial encounters as well; (2) elements of permanence, in that development transports this heritage of knowledge and practices into the contemporary world, lending it new life in the form of post-World War II development; (3) elements of a capillary nature and of depth, in that development has been spatially widespread, occurring in the most diverse realms of social life; (4) elements of historicity, in that development has displayed differences in doctrine over time; and (5) even elements of contingency, if we recognize that conjunctures of development, when observed as specific instances, are likewise arenas of negotiation, though the distribution of power within these arenas is almost always lopsided.

Representative of this line of research, two authors and two of their studies seem particularly appropriate to the present article. The first is Arturo Escobar and his Encountering Development: The Making and Unmaking of the Third World, first published in $1995 .^{7}$ According to the arguments in this book, the immediate post-World War II period witnessed the emergence of a particular way of viewing and actuating relations between societies and people. This was "development," a set of representations and an approach for intervening in reality that sought to employ a means of knowledge and a way of introducing capital and technology in order to radically transform societies considered more impoverished or backwards, according to the prevailing standards for the richest social formations in the Euro-American world; these societies would be molded in the image of a modern West that was in the process of becoming a planetary phenomenon. Development is thus drawn from and manifested through a "development apparatus," that is, a set of institutions, knowledge, methods, techniques, and technologies. Such apparatuses and their interconnections strive to accomplish their assigned purpose of meeting the needs of the underdevelopment/development relation and solving its problems, while simultaneously contributing to the very construction of this arena or domain of knowledge, power, and social practices (Escobar, 1998, p.56-99, 107-111).

Functional international organizations like UNESCO, the UN's Food and Agriculture Organization (FAO), the World Health Organization (WHO), and PAHO, along with economic and financial aid bodies like the World Bank and the International Monetary Fund (IMF), not only engaged in this movement but were also in good part responsible for producing the very conditions necessary for it. Imbued with a generalized confidence in science and technology and in planning methods, the development perspective called for ubiquitous, integrated, systematic, and territorially widespread interventions. Its intention was to be largely multisector and grounded on forms of collaboration between institutions and countries, reiterating the importance of international bodies and of technical cooperation as part of their agencies and practices (Escobar, 1998, p.56-99, 107-111).

Escobar has an incontestably clear view of the conception and operation of development as a way of understanding and intervening in the world. According to this author, the emergence of development and its constellation of means of knowledge and forms of action responded to a need to renew forms of North-South domination within the context of a rapidly changing international system. Accompanied by a sense of urgency, these changes transpired against the following backdrop: the end of the 1939-1945 world conflict, the economic destruction of Eastern Europe, the subsequent dismantling of Europe's remaining colonial empires, the establishment of the United States as the world's new hegemonic power, the cementing of 
the USSR as a competing power, and the emergence of the Cold War as a modus convivendi between the latter two.

Within this new scenario, development was one of the strategies aimed at the geopolitical containment of the dreaded advance of communist positions, which traces its roots to the United States, center of the international system. Through the transfer of capital and technical assistance, development promoted the image of a future with a more equitable distribution of wealth among nations and with steadily rising standards of living for people who had been victims of backwardness. To this end, these populations would have to be subjected to all types of modernizing interventions, pervaded by a necessary economic rationale and yielding a kind of "economization" of social life.

The literature contains no small number of criticisms of this notion of colonization of the world by development, as proposed by Escobar and this modality of post-modern thought. ${ }^{8}$ It would be unfair, however, to read Escobar as responsible for a monolithic conception of development and the proposition of only a harsh, or absolute, unidirectionality in the production of its representations and the operation of its apparatuses. In the countries targeted for cooperation efforts by the development enterprise, the national elites played a noteworthy role in defining the terms under which these initiatives were absorbed and also in the very formulation of demands. On the other hand, as regards the thinking of the Economic Commission for Latin America (ECLA; now ECLAC) and authors of Marxist inspiration like Samir Amim, Fernando Henrique Cardoso, and Enzo Faleto, Escobar suggests that these perspectives passed sentence on diverse aspects of dominant thought, including the theory of international trade. ${ }^{9}$

A second applicable author is Gilbert Rist (2002), who in 1997 published The History of Development: From Western Origins to Global Faith, revised and expanded in 2002. ${ }^{10}$ His thoughts on development have several points in common with Escobar's arguments, including a patently negative evaluation of the results achieved by development endeavors and an ultimate goal of establishing a post-developmentalist program.

The two authors share an equally comprehensive understanding of development as a cultural phenomenon. However, when Rist couches development as a belief system, or as an element in a "religion of modernity," he broadens the temporal span of development, in a manner of speaking. He ties its origins to longer-standing Western views on evolution, progress, and history, related to the secularization of life and the affirmation of the human potential for accumulating knowledge and achieving transformation; this eventually cemented the idea that human production can enjoy permanent growth, or "unending progress," viewed as a positive process, as natural as it is necessary (Rist, 2002, p.43-46). As part of this historical journey, development melds with the very process of goods production under capitalism and its impact on the environment and on human relations. At the same time, development is far from being restricted to the relations between central countries and those on the periphery but is rather just as relevant, or more so, to the workings of any and all social formations swept up in its dynamics.

From Rist's viewpoint, the brand of development that was "invented," or re-invented, at the close of World War II introduced a fundamental innovation: the idea of continuity posited in the duo underdevelopment/development. The notion of discontinuity and 
rupture inherent to juxtapositions like metropolis/colony, dependency/independence, and traditional/modern (along with similar pairings found in colonial and pre-developmentalist representations) was consequently replaced by the idea of belonging, that is, of a shared destiny and historical continuity, thereby recasting the issue of North-South in new terms (Rist, 2002, p.90-92).

In the second half of the twentieth century, this historical continuity traversed a series of periods defined by the enunciations found in references that Rist selects as representative of the course of development. To his way of thinking, the 1950s were a time when development "was still incubating," which spawned the introduction of international development agencies and their initiatives as one of the means of achieving development. The decade, Rist tells us, was marked by essentially economic understandings of development, measured almost strictly by the impact of growth on each country's GDP (Rist, 2002, p.89). The close of the decade and the dawn of the 1960s brought the announcement of the UN Decade of Development. One of the main innovations of the period was the embracing of less economic reductionism in enunciations. As a result, greater importance was accorded the "human factor," the mobilization of "human resources," and matters like education and health (p.90-92).

The second half of the 1950s and the subsequent decade also witnessed the emergence or strengthening of the most prolific development theories. Roughly speaking, they can be exemplified here by two polar propositions. On the one hand, we have Walt Rostow's "evolutionary developmentalism" and, on the other (in the wake of ECLA thought), dependency theory. In the first case, Rostow advocated international aid in combination with modernizing reforms to foster the "take-off" of underdeveloped economies, directed towards their integration into a worldwide society of mass consumption as a common, universal destiny. The second case represented the apex of a formulation by intellectuals "from the South," which stressed the unequal nature of international exchange and the steady deterioration of its terms to the detriment of commodity exporting nations. According to these analyses, development fostered "development within dependency" in conjunction with permanent disparities between the nations of the center and the periphery, in the bestcase scenario (Rist, 2002, p.109-110).

What we can glean from this discussion is that the ideas on the relations between health, economics, and development as presented by PAHO director Abraham Horwitz from the turn of the 1950s to the 1960s were unquestionably part of a more general framework of development, which displayed a common grammar while still allowing for disputes and tensions between different projects. While not moving beyond the imagination or agendas of development, the period saw (among other identifiable nuances): a shift in US policy, more open towards the perspective of a reform version of international aid; the transformation of precepts such as those formulated by Walter Rostow into a hemispheric policy, under the leadership of the United States; and the simultaneous emergence within ECLA of an economics critical of development. In cognitive and political-ideological terms, the inter-American context thus formed an arena of competing views about the purposes of development and the means for achieving it. 


\section{Development and inter-American relations: a US shift in the shadow of revolution}

From the mid-1950s to the early 1960s, a sequence of events in political history and diplomacy on the American continent pushed the topic of international aid for development to the very fore. During the course of these events, social policies in areas like health and education gradually made their way onto the agenda. These episodes included the reverberation in the United States and Latin America of a proclaimed "Soviet economic offensive" in 1956, the inauguration of Operation Pan America in 1958, the Cuban Revolution in 1959, signature of the Act of Bogota in 1960, and the launching of the Alliance for Progress in 1961.

Operation Pan America, an initiative of the Juscelino Kubitschek administration, was intended to revise Pan-Americanism in the context of the Cold War and of rising antiAmerican sentiment among the Latin American public. The plan defended intentional US assistance targeting the development of countries in the South, which should include sizeable public investments as part of a shared pact embracing "hemispheric values" and therefore anti-communist positions. The operation was essentially economic in substance (Silva, 1992, p.18-19; Ribeiro, 2006, p.47-53).

Although US interest in this type of commitment was at first cool, the Operation nevertheless prompted the formation of a Special Committee of the Council of the OAS, which came to be known as the Committee of 21, a top-level study group comprising representatives of 21 countries in the region, who were assigned to examine and propose measures and above all to expand economic cooperation. ${ }^{11}$ The outbreak of the Cuban Revolution, however, augmented Washington's worry about the communist ideology making inroads in Latin America. When the Committee of 21 met in Bogota for a regular meeting in 1960, still under the Eisenhower administration, US representatives not only expressed greater sympathy about coordinated, multilateral action for development but also managed to add the matter of social policies to the agenda. This add-on, according to its designers, was part of an effort both to mitigate social hardships in response to urgent needs and also to further productivity and strengthen economic development in hopes of holding back the advance of socialism (Silva, 1992, p.22-30). In the opinion of some analysts, the Eisenhower administration modified its stance on technical aid for development. If the prime idea, prior to 1956, had been that capitalist entrepreneurs should be responsible for the bulk of development investments while US government agencies should organize and foster international technical assistance, starting that year the idea that nation-states should play a bigger role in major strategic investments began to make headway, albeit gradually and somewhat reluctantly (Ribeiro, 2006, p.42-53; Sewell, 2008, p.844-846). ${ }^{12}$

It was during this period that the political environments in Washington and in Latin America's major capitals increased their receptivity to more reformist attitudes towards the development process. The liberalism of the early Eisenhower years, averse to economic planning and public investment in infrastructure works, gave way to Rostow's evolutionary prescription, to ECLA's "industrial" reformism, and to the economic planning concepts that both of the former perspectives could be said to embrace (Silva, 2011, p.17-20; Bielschowsky, 1998, part IV). American positions nonetheless tended to emphasize the promotion of social policies, an outlook that could already be detected in the run-up to the Committee 
of 21 meeting (which signed the Act of Bogota) and in the earliest proposals of the Alliance for Progress.

The Act of Bogota, adopted by the OAS Council in September 1960, recognized that while Latin American countries had made important individual efforts to cope with their social and economic problems, these efforts would only be successful if accompanied by a new, energetic program of inter-American cooperation. The Act also recognized that even if an urgent reinforcement of programs reaped major rewards in the economic field, it would take some time for the majority of the population to feel any impact on their living conditions. In order to speed up the process, the US government came forward with the idea of creating an inter-American fund for social development, to be managed by the Inter-American Development Bank (IDB), created in 1959 within the framework of Operation Pan America (OEA, 1960, preamble and item II).

In the economic realm, the document stated that the capital-exporting countries of North America and Western Europe and international credit agencies would have to expand their financial aid, in keeping with the principles of Operation Pan America. This increase should take into account the need for flexibility, including possible loan amortization payments in local currencies to prevent debt from further debilitating these countries' balances of payments. Technical assistance should also be provided for designing projects - along with "the monetary, fiscal, and exchange policies required to carry them out"13 - and for the formulation of national development plans (OEA, 13 set. 1960, item III).

But the Act of Bogota advanced more in the realm of social policy. It proposed that additional measures be implemented in the administration of taxes and tariffs, ownership and land use, education and training, and health and housing. Accordingly, the document recommended measures designed to promote land tenure legislation that would foster a more equitable distribution of land ownership and would tax idle land; provide small farmers with agricultural credit, including those working under cooperative schemes; establish land settlement programs in abandoned or underutilized areas; build transportation infrastructure in unserviced areas; incentivize the construction of low-cost housing while respecting quality standards; undertake sanitary works, adopting innovative forms of public and private credit and financing; conduct mass education programs to eradicate illiteracy; promote technical and scientific training in the industrial arts and sciences, accentuating practical application for development; and promote basic rural education, including therein the study of agricultural techniques, business, housing, and sanitation (without exhausting the list).

In the sphere of health, ${ }^{14}$ the Act of Bogota proposed to: re-examine public health policies, with particular emphasis on the expansion of national health services, especially those aimed at lowering infant mortality; implement progressive development of health insurance systems to address maternity, accident, and disability insurance in urban and rural areas; provide health care in remote and impoverished areas; strengthen campaigns to control or wipe out communicable diseases, with special attention to the eradication of malaria; strengthen nutrition programs targeting populations with serious nutritional needs; expand the provision of water and sewer facilities; and train public health officials and technicians (OEA, 13 set. 1960, item I). 
As an international policy document, the Act of Bogota endorsed the interconnectedness of economic progress and improved social conditions as parts of one same development process and indicated the subsequent steps for the urgent formulation of a hemispheric policy in tune with these guidelines. The document suggested that "within sixty days" the Council of the OAS should convene a special meeting of senior government representatives to lay out concrete proposals for implementing a broad program of multilateral aid. The resultant work group was the Committee of 21, which received contributions from specialists in a range of fields. As we will see later, PAHO was a steady presence at its meetings and the committee was an active participant in the formulation of the proposals that were presented for debate at the Punta del Este Conference.

Six precise months following signature of the Act of Bogota, that is, on March 13, 1961, the newly inaugurated president of the United States, John F. Kennedy, made the inaugural speech of the Alliance for Progress before an audience comprising the Latin American diplomatic corps in Washington and US Congressmen. In explicit consonance with the "spirit" of Operation Pan America and the recommendations of the Act of Bogota, the Alliance for Progress was intended to be a ten-year program to foster economic and social development in Latin America and the Caribbean; its finer points would be hammered out during a ministerial meeting of the Inter-American Economic and Social Council of the OAS, to be convened for this purpose. Initially financed with funds authorized by the US Congress, the program's basic principles were tailored to defending what were deemed the hemisphere's basic values, such as democracy, individual freedom, and the market economy. In this regard, the Alliance reaffirmed the idea that the relations between development, democracy, and hemispheric security in the face of creeping communism were interconnected, a relation that had been formulated simultaneously within Operation Pan America and by US liberal reformist thought in the mid-1950s (Ish-Shalom, 2006, p.293-294).

Excerpts from Kennedy's address, which is often cited in the literature, serve as a fine illustration of the spirit that moved US government leaders to draw up and launch the program:

Never - in the long history of our hemisphere - has this dream been nearer to fulfillment - and never has it been in greater danger. The genius of our scientists has given us the tools to bring abundance to our land, strength to our industry, and knowledge to our people. For the first time we have the capacity to strike off the remaining bonds of poverty and ignorance - to free our people for the spiritual and intellectual fulfillment which has always been the goal of our civilization. Yet at this very moment of maximum opportunity, we confront the same forces which have imperiled America throughout its history - the alien forces which once again seek to impose the despotisms of the old world on the people of the new (Kennedy, 13 mar. 1961, p.2).

This is inarguably an exemplary expression of a matchless belief in the redemptive power of science and technology and of a positive attitude about where the future was headed, in an enunciation that combines knowledge, technology, industry, abundance, and spiritual and intellectual fulfillment. At the same time, few pages are so representative of how this optimism, framed by an excluding Pan-Americanism and by the spirit of the Cold War, marched hand-in-hand with the fear of a nation that had cast itself as the guardian of an 
imperiled, virtuous New World civilization and that was busy marshalling nebulous elements of a shared identity in order to project into the present and future equally nebulous threats, brought forward out of the past. These same projections implied a very real, concrete hostility towards any dissident of the projected unity, and so it was that US intelligence agents and contingents of Cuban exiles worked together to prepare an undercover military invasion of Cuba, which took place exactly 34 days later - and which, as we well know, met with failure.

In addition to this spirit, where realpolitik and considerations of an ideological and ethical order coexist, the Alliance was the response to a growing sense of urgency about the need for (in Kennedy's words) "a vast cooperative effort, unparalleled in magnitude and nobility of purpose, to satisfy the basic needs of the American people for homes, work and land, health and schools - techo, trabajo y tierra, salud y escuela" (1961, p.3), with the phrase concluded in Spanish as a show of affability towards Spanish speakers. To enforce this agenda for development, concrete initiatives would range from measures such as fostering the formation of integrated markets and the management of commodity prices to the formulation of hemispheric policies and technical assistance in nutrition, housing, education, and health.

The countries of the Americas formally entered into the Alliance for Progress with the joint signing of the Charter and Declaration of Punta del Este on August 17, 1961, on the occasion of the Special Meeting of the Inter-American Economic and Social Council, held at the ministerial level in that Uruguayan city. Discussion of the Alliance at the meeting was anything but smooth (Botega, 2009, p.156-175).

Indelibly marked by the Cuban issue (which at that point in time embodied the Cold War in the Americas), the Uruguayan meeting was the stage to debates over development models. These debates are better known for the sharply anti-imperialist remarks of the Cuban representative, Ernesto Che Guevara, but countries like Argentina and Brazil also took discordant stances on the terms of the US proposal, even though it had been well received as a promising initiative.

The main critique lodged by these countries was that the US proposal paid scant attention to the matter of economic development, especially industrial development, as compared to the social agenda. ${ }^{15}$ For instance, in the preparations leading up to the meeting itself, the governments of Brazil and Argentina presented economic analysis documents where they sketched out a regional development project in which the dominant idea was that an agenda for Latin America should not stress projects of an assistentialist nature but should firmly encompass financing for industrialization and economic production projects in general. ${ }^{16}$ Faced with these criticisms, the US representatives went along with the inclusion of the industrial component as part of aid and agreed to downplay agrarian reform, an especially delicate subject in the eyes of the South American elites, to cite but two examples of the changes made (Botega, 2009, p.160-167).

As a result, the Charter of Punta del Este can be seen as a compromise between the US stance and the developmentalist aspirations of some of Latin America's most important countries. It can also be said that the program foreshadowed certain relevant elements of the so-called basic-needs policy, which, in the view of some analysts, set the tone for international cooperation as conducted by the World Bank starting in the late 1960s and especially as of the 1970s (Edelman, Haugerud, 2005b, p.7). 
The Alliance for Progress was defined as a major cooperative effort that would hasten the economic and social development of participating countries, driven towards well-being and equal opportunities "in democratic societies adapted to their own needs and desires" (OEA, 1961, p.33). The twelve fundamental goals directed at achieving this objective can be summarized as follows: (1) substantial and "sustained" (already using today's terminology) growth of per capita income and a more equitable distribution of this development; (2) a more equitable distribution of national income, higher savings, and greater investment; (3) diversification of national economic structures through changes in foreign trade products; (4) acceleration of the process of "rational" industrialization; (5) higher agricultural productivity and improved storage, transportation, and marketing services; (6) agrarian reform programs, "in accordance with the characteristics of each country," supplemented by lines of credit and technical assistance, and with equitable land tenure and decent labor systems; (7) elimination of adult illiteracy by 1970 and modernization and expansion of secondary, vocational, and higher education, while also reinforcing the capacity for basic and applied research; (8) increased life expectancy at birth by a minimum of five years and an increased ability to learn and produce through improvements to health: (9) construction of a suitable number of low-cost houses; (10) the fostering of stable price levels; (11) promotion and strengthening of economic integration agreements, including those meant to create a Latin America common market; and, lastly, (12) promotion of cooperative programs designed to forestall excessive fluctuations in earnings on the export of primary products and adoption of the measures needed to facilitate the access of Latin American exports to international markets (OEA, 1961, p.33-36).

The Charter and Declaration of Punta del Este were accompanied by specialized documents also signed during the meeting, one of which centered on health: the "Alliance for Progress Ten-Year Public Health Plan" (OEA, 1961). Before presenting this document and discussing how health fit in to the foundational documents of the Alliance for Progress, it would be well worth our while to examine how PAHO interacted with this diplomatic agenda for development assistance.

\section{PAHO and mediation between health and development, according to Abraham Horwitz}

From the programmatic documents produced and released by PAHO and the articles published from the late 1950s to early 1960s in its leading periodical, Boletín de la Oficina Sanitaria Pan-americana, we can ascertain that the organization, through its director Abraham Horwitz, sought to express and convey the notion of a meaningful relation between economics, development, and health, with the last of these forming part of an agenda as formulated in inter-American forums until then.

The first article expressly devoted to these discussions was penned by Horwitz (1959) himself and came out in Boletín in 1959. Titled "Relaciones entre salud y desarrollo económico," the article had originally been presented as a paper at the meeting of the Special Committee of the Council of the OAS held in Buenos Aires, Argentina, in April-May 1959, in other words, at the second of the meetings (and the first after the Cuban Revolution) of the Committee of 
21 , the group charged with proposing mechanisms and measures for advancing multilateral cooperation within the framework of Operation Pan America.

The second article, likewise written by Horwitz (1961a), reproduced a document presented by the PAHO director at the third meeting of the same committee, in September 1960 - the meeting that led to the signing of the Act of Bogota. In December 1960, Horwitz was back presenting the same discussion at the Fourth Mexican Congress on Public Health. This paper was also published in Boletin in August 1961 while the conference was taking place in Uruguay.

The topic would return to the pages of PAHO's key publication twice more in 1961, again in the form of articles signed by Horwitz but in these two cases speaking to well-being and economic development and to social policy planning. ${ }^{17}$ Both papers were presented at the Special Meeting of the Inter-American Economic and Social Council, which produced the Charter of Punta del Este and the Alliance for Progress' Ten-Year Public Health Plan.

PAHO's contributions to the special meeting were not, however, limited to these two documents written by its director. The agency also presented an institutional document entitled Hechos sobre problemas de salud, which focused on such matters as human resources, nutrition, infectious contagious diseases (malaria, tuberculosis, smallpox, and others), and water and sanitation; it was published in July 1961 as an issue of the series Publicaciones Varias (OPAS, 1961).

Meanwhile, also in 1960 and as an issue of the same series, Horwitz published a highquality, illustrated booklet called On health and wealth (released in PAHO's three official languages: English, Spanish, and Portuguese); he circulated it as a PAHO position paper right when social policy was becoming an integral part of diplomatic debates on the continent. ${ }^{18}$

Relations between economics and health had long been one of the topics addressed at WHO forums. The Fifth World Health Assembly, held in 1952, listed the subject as one of its planned technical discussions, although no debate actually transpired. Instead, on this occasion guests Charles-Edward Winslow and Gunnar Myrdal ${ }^{19}$ read papers on, respectively, the economic value of preventive medicine and the economic implications of health. While recognizing the fundamental importance of human values, Winslow spoke about the potential economic returns on public health investments through the application of technologies like DDT, penicillin, and immunizers. He also stressed the need for promoting the organization of basic services that were sufficiently thoroughgoing, hierarchical, and permanent. He further argued for community participation right from the planning stages of health initiatives and advocated approaches like those derived from cultural anthropology. His ideal image of development presumed that biological and social evolution were part of an articulated whole, wherein a harmonious world order would be the final stage in the planet's social evolution "until we penetrate interstellar space" (Winslow, 1952, p.200).

Myrdal presented his notion of cumulative social causation, according to which alterations to a determined element of social life can set off a chain-reaction of successively powerful changes. Hence the need for a multi-front line of attack on the development problem that would afford the greatest possible integration of economic, social, political, and cultural aspects, wherein education was deemed fundamental. Identifying the need for agrarian reform in developing countries, Myrdal also expressed sharp concern about the level of domestic savings and the formation of productive capital. When these are missing, Myrdal 
stressed, support for health initiatives might actually aggravate problems, since population numbers might rise without a corresponding increase in the production of foodstuffs and other essential resources (Myrdal, 1952, p.206-208). Astute as they were, these contributions had no great immediate impact, at least not in the context of inter-American health. At the close of the decade, however, when the topic had earned a notable presence on the regional agenda, Myrdal's work would quickly be brought into play.

Although the matter of the relations between health and development was implicit, the subject per se was essentially absent from PAHO's debates and concerns until social policy burgeoned as a focus of attention within discussions on international aid and development. While these topics were in the process of moving out front, as we saw, the agency prepared and published documents as input to the formal debates, first at the Committee of 21 and then at the Special Meeting in Punta del Este. We could say that PAHO felt driven, with Abraham Horwitz throwing his personal efforts into the endeavor and signing a number of these papers.

In his first address before the Committee of 21 , Horwitz $(1959$, p.93) took as his point of departure the absolute necessity of integrating health actions with initiatives designed to foster economic growth, in view of the "steady, reciprocal interrelation between health, economics, and social progress". Against this backdrop, he highlighted the economic value of labor and health as foundations of social progress and pondered the economic loss represented by each human being who did not reach productive age. As we will see, in this paper and the others that followed immediately thereafter, Horwitz pressed home the ultimate humanistic meaning of interventions in health and of other social policies. ${ }^{20}$ These provisos notwithstanding, a greater emphasis on economic rationality in health expenditures can be identified in the articles and studies that came out before the Punta del Este Conference (Horwitz, 1959, 1960a, 1960b, 1961a, 1961b, 1961c).

In his talk before the second meeting of the Committee of 21, in 1959, the PAHO director began formulating what he would soon call the "economic cycle of disease," which acquired final form in his work published the following year. Represented by a circular diagram composed of two conjoined spirals, the first spiral indicated that low economic production engenders bare subsistence income, in turn producing deficient nutrition, inadequate housing, and poor education, next leading in turn to disease. Disease then lowers human energy, which completes the first spiral by occasioning further low economic production. In the second spiral, the heavy onus of disease generates high investments in curative medicine; in countries with more limited resources, this leads to lower investment in preventive care and public health, perpetuating more disease. So the second vicious spiral also closes with low social production, despite heavy spending in medical care (Horwitz, 1959, p.24, 1960a, p.3-4).

This formulation is a clear development of Gunnar Myrdal's vicious circle of poverty, according to which, in impoverished social formations, the intimate relation between the issues of health, education, housing, food, and economic production, rooted in the sphere of human culture, demands a comprehensive approach that takes into account complex phenomena and that conjoins economic growth policies with policies to improve living conditions. It is worth noting that this type of circular image (likewise used by Winslow in his 1952 conference, mentioned earlier) is particularly common in development formulations, 
either to identify backwardness, where negative conditions are mutually and perpetually reinforced, or, in a positive sense, to illustrate the virtuous, cumulative repetition of growth factors, once the previous circularity has been sustainably broken.

We note a special concern with outlining Latin America's key economic problems and their social implications. In the texts available prior to the conference, the following main concerns were underscored: a sharp, steady rise in population with no corresponding rise in production, especially of food; inadequate land use and a regional tendency towards the export of monocultures, with international prices falling; and accelerated urbanization but without any satisfactory urban development.

In regard to the (recurrent) population issue, in no case did Horwitz expressly recommend the adoption of population control initiatives. As to land use and ownership (one of the themes dear to the agenda agreed upon under the Act of Bogota), the issue only begins to show up in the discourse of the PAHO director after release of the latter document, in other words, in the texts published in 1961. We can also see that in Horwitz's arguments, the theme of industrialization receives nowhere near the attention it gets, for example, in the foundational documents of Operation Pan America and in ECLA texts. For Horwitz (1960a, p.10), incipient industrialization is merely identified as one of the inherent problems when the accelerated growth of cities is not accompanied by heavy investment in urban infrastructure - a sign of stagnant economies.

Returning to the discussion of the economic cycle of disease in his article published in August 1961 in the context of the Punta del Este Conference, Horwitz uses the work of Walt Rostow to paint a clearer picture of the role of health and social policies in the process of modernization. According to Horwitz (1961a, p.99), health and all else had to be made to exert a positive influence on a set of self-articulated factors, since "the shortcomings of one sector are reinforced by limitations in others," especially in developing countries. Therefore, only a multipronged, integrated approach would make it possible "to move from a traditional society, in Rostow's scheme, to a period of maturity and a high level of consumption" (p.99).

Citing a long excerpt from Chilean economist Alberto Baltra Cortez, the PAHO director adds to his argument the relevance of "non-economic and extra-economic" factors of development, deemed fundamental (Horwitz, 1961a, p.99). Among these factors are education, health, scientific traditions, capacity for innovation, social cohesion, and cooperative spirit, in addition to moral and ethical values and their expression in the realm of legal, political, administrative, and religious institutions (p.99). ${ }^{21}$

Horwitz asserts his belief in the reach of rationally conceived and scientifically grounded human intervention and its ability to guide human societies towards progress. In order to make this possible, according to Horwitz, the capacity to plan and coordinate policies would necessarily have to be fostered. In this regard, he was especially optimistic about recent processes and events, including ECLA's contributions in the sphere of economic information, Operation Pan America, the Committee of 21, the foundation of the IDB, and the creation of the Special Fund for Social Development (Horwitz, 1959, p.99, 1960a, p.16$18,1961 \mathrm{a}, \mathrm{p} .102)$. In these passages, as in others, Horwitz's thought is a typical expression of development as a discursive regime; it is essentially optimistic about the potential of 
development and about the process and meaning of the construction of what Escobar (1998) calls its "apparatus."

As to financing, Horwitz makes a distinction between directly productive capital and capital with "social benefits," the latter including investments in health as well as investments in transportation, water and sewer, education, energy, and so on (Horwitz, 1959, p.99-100). He was very emphatic about the need for public, governmental, and international commitment to funding this type of infrastructure, even though he felt it necessary to stress the imperative of charging users for water supply services, grounded in a principle of self-financing.

In his 1959 article and in On health and wealth (1960), although Horwitz endeavors to accentuate how public health plays a preponderant role in solving issues related to well-being, he admits - in an apparent paradox - that: "Eighteenth-century statistics show a drop in general mortality ... result[ing] from developments other than the improvement of medical care ... [but rather from] pasteurized milk ... [and] ... tuberculosis clinics ... Improved land cultivation and food distribution probably played a part in this phenomenon" (Horwitz, 1960a, p.6).

Here Horwitz is demonstrating his familiarity with the arguments of authors like Thomas McKeown, who contend that population growth in European countries down through the eighteenth century was primarily a result of improvements, above all in housing and diet. ${ }^{22}$ But even if that were true, Horwitz felt, it did not invalidate the importance of measures to prevent and treat diseases "when applied within a balanced program of economic development" (Horwitz, 1960a, p.6).

Asserting health as a social theme of development appears to be Horwitz's central concern in these texts. To this end, and once again relying on Gunnar Myrdal, he recognizes that the success of any public health program depends on its integration with a process of social evolution (Horwitz, 1960a, p.15-16). Ergo, public health initiatives with potentially immediate results should be matched by equal advances in production conditions and well-being, so that progress can transpire sustainably (Horwitz, 1959, p.98-99, 1961b, p.379-380). It may also be added that the centrality ascribed to health, and to social policies in general, was likewise an expression of a necessarily extra-economic valorization of the human dimension, to some extent irreducible to strictly economic aspects.

With these relations defined, Horwitz goes on to list the themes of greatest public health and economic impact: the prevention and combat of infectious contagious diseases (especially malaria, whose eradication campaign he praises while adding the caveat that it has "now [been] complicated by the resistance to insecticides developed by mosquitoes") (Horwitz, 1960a, p.13); basic sanitation, which should be implemented through economically sustainable programs; food production and nutrition programs; and decent housing. He goes on to stipulate education as the prerequisite path to "sources of knowledge and information" (p.13-15), essential for people to become part of the world of work and production and for public health awareness. It should be noted that in the documents analyzed so far, on only one occasion, and then in a very cursory fashion (1961b, p.385), does Horwitz bring up the need to expand and improve healthcare services.

As to international organizations, Horwitz envisioned them operating within the framework of a new Pan-Americanism, inaugurated under OAS initiatives and the creation 
of the Committee of 21 . He held that international organizations had the dual role of supporting funding and providing technical assistance, in the form of "advisory assistance." As regards funding, he lauded the establishment of the IDB and the inclusion of social programs among items eligible for financing. In underlining the importance of this inclusion, Horwitz said that the OAS program includes the doctrine that health is a basic complement to the economy and that the OAS should therefore make public health an ongoing chapter in its projects (Horwitz, 1960a, p.18). In terms of technical assistance, Horwitz highlighted the role that PAHO should play; given its status as a specialized agency, he pointed out that it was the most qualified institution to help draw up the "public health plans" to be submitted for government funding; in other words, PAHO was particularly tailored to provide technical advisory services (p.17-18).

In the documents that Horwitz presented at the Punta del Este Conference itself, he returns to these themes (Horwitz, 1961b, 1961c). However, we can detect some shifts in emphasis and omissions or additions of arguments that are worth noting. First, the PAHO director is much more direct in his affirmation that health is above all the precondition for development and thus he abandons the argument more attune to McKeown's thesis, according to which improved socioeconomic conditions had been more determinant to the improvement of health conditions for the people of Western Europe. At the same time, Horwitz points to the inefficacy of economic policies that "failed to pay heed primarily to individual and collective well-being" (Horwitz, 1961b, p.379). Ergo, though he does not cast aside the economic foundation of his declarations, he does, on the one hand, underscore the value of health policies and programs "in and of themselves" and of their role as a precondition for economic development; on the other, he ascribes to the latter the ultimate goal of fostering improved levels of fulfillment and well-being for individuals and peoples.

Second, in listing the concrete problems then begging for immediate attention, these articles by and large reiterate the agenda laid out in On health and wealth (Horwitz, 1960a). But they do place added emphasis on the potential instruments for confronting these problems, to wit, the planning, organization, and administration of health services, human resource training, and scientific research (Horwitz, 1961b, p.381).

The trend at that time was to make planning the panacea for all evils. As one of the most widespread "development apparatuses," planning was conceived to be as integral and comprehensive as possible and capable of functioning in accord with the various domains of social life in all their complexity; as such, it was designed to be the manifestation par excellence of the introduction of science and technology into government processes, guaranteeing the efficiency and efficacy of government action. The debates in Punta del Este reflected this confidence, above all in the realm of economic and social planning. According to Horwitz, there was a consensus among inter-American health institutions about the need for regional and national economic and social development plans, for regional and national health plans, and for increasingly accurate, sophisticated information sources for use in diagnosing situations and controlling results. Concerns about the quality of health management came together with this attention to the scope and effectiveness of government processes, especially those linked directly to the development plans and projects to be implemented (Rivera, Artmann, 2012, chap.1; Horwitz, 1961b, p.381). 
Equally firm confidence was placed in the power of science and technology, a sentiment particularly typical of development. The thinking was that a good share of the technological solutions for confronting the chief problems were already at hand and that scientific research and technological development would prove wholly capable of furnishing any further innovations that might be called for (Horwitz, 1961c, p.387). As regards human resources in the area of health, this was perhaps the first time Horwitz addressed the matter as a specific concern in its own right, one that deserved to be the object of planning and of specific programmatic initiatives (Horwitz, 1961b, p.385). ${ }^{23}$

It was in "Planificación del desarrollo económico y social em América Latina" (Horwitz, 1961b) that Horwitz first called attention to the need to build hospitals and create a network of outside clinics; these comments were supplemented by strict compliance with the precepts of rational administration. In his own words: "Current hospitals can serve a much larger number of patients if their outside clinics are better organized and if the average hospital stay is reduced to limits compatible with the requirements of rational treatment" (p.385).

If previous documents had made only infrequent mention of the conference's central economic themes (i.e., support for industrialization and initiatives designed to engender more stable, higher prices for Latin America's major export commodities), any such mention is wholly absent from the documents presented by Horwitz at this debate. The same holds true for the reforms introduced into the discussion especially after the Act of Bogota. No mention was made of agrarian or fiscal reform, except perhaps a brief, indirect allusion to the need for economic policies that would truly boost personal income (Horwitz, 1961c, p.387-388). Likewise missing from the final documents was the issue of soaring population growth and the ensuing health implications.

As mentioned earlier, the main outcome of the Uruguayan meeting in the realm of health was the launching of the Ten-Year Public Health Plan under the auspices of the Alliance for Progress. Following the doctrinaire recommendations presented in preparatory papers, the document defined long-term goals and immediate initiatives: the initial long-term goal should be the implementation of national health plans over the coming ten years; as support in drafting these plans, each ministry should set up bodies specialized in planning and follow-up, while the capacity to gather and analyze statistical data should also be enhanced. Special attention should be given to human resource training, in accordance with prior studies that would ascertain the number of professionals needed at the college, vocational, and technical levels for both preventive and curative work; furthermore, those already working in these sectors should receive additional training while new contingents should be progressively trained; lastly, the requisite training facilities should be expanded or set up (OEA, 1961, Anexo A21).

Similarly consonant with preparatory documents, the ten-year plan recommended that health service administration be upgraded, that preventive and curative work be integrated, and that full use be made of the storehouse of knowledge and technological means then available for tackling health problems. Lastly, and also as a long-term goal, legal frameworks should be put in place to guarantee adequate health protection at the sites of industrial, agricultural, and urbanization initiatives related to the development drive. 
In regard to immediate or short-term actions, the document reflects its authors' and signatories' concern with ensuring the continuity of existing initiatives, explicitly in areas like the control and eradication of communicable diseases, sanitation, nutrition, health care, and women's and children's health, in other words, the main items on PAHO's agenda as enforced after World War II. Measurable quantitative goals were also proposed, such as providing water and sewer services to $70 \%$ of the urban population and $50 \%$ of the rural; cutting infant mortality in half; and eradicating malaria and smallpox. Some less precise goals were also stipulated, like "substantially improving food and nutrition for the most vulnerable" (OEA, 1961, p.60).

Although the ten-year health plan established rather specific goals, it was much more a set of guidelines for designing in-depth regional plans to underpin the formulation of national health initiatives. Express recommendations were likewise included in Resolution A.4 (OEA, 1961) of the Punta del Este meeting, meant to convoke expert study groups that would draft appropriately detailed recommendations. In terms of the agenda of programmatic initiatives, the final document on the whole ratified the guidelines endorsed by PAHO and its director.

Yet both the ten-year plan and the supplementary resolution mentioned above went even further, endorsing PAHO as a specialized agency responsible for organizing the regional planning process and also for providing any technical assistance as required to draft and implement plans, programs, and projects. Thus, at the close of the Special Meeting of the Inter-American Economic and Social Council of the OAS, in 1961 - an event that established the basic terms of the Alliance for Progress and an inter-American agenda for what would be the first Decade of Development - PAHO had reasserted its role and its centrality as a specialized regional agency. Horwitz's efforts towards this end had been entirely successful.

\section{Final considerations}

By the close of the 1950s, the regional debate over the meaning and direction of interAmerican cooperation had grown quite heated. After initial reluctance on the part of the United States, a relative consensus was forged among governments and their chancelleries about the need for joint initiatives to accelerate the development process. ${ }^{24}$ However, Latin Americans and North Americans were still divided over the nature of international aid and its short-, medium-, and long-term purposes (with arguments within the former group displaying their own varying hues). PAHO joined the debate right at the moment when, at the initiative of the United States, greater programmatic emphasis began to place on the themes of social policy and social reforms, such as agrarian and fiscal reform, education, health, and housing.

Horwitz began by working to establish the economic content of health initiatives and the reciprocity of the implications born of the relation between health and economic development, without abandoning (what should be) ethical and humanistic foundations. He drew from distinct traditions in developing his argument. He "dared" to mention arguments from McKeown's thesis, perhaps to show that he was abreast of the discussion on the limitations of focusing solely on health care and the importance of social conditions. In terms of development studies per se, he relied on formulations by Rostow and Myrdal and on 
references to ECLA, without dwelling on any possible distinctions between these positions; he was more concerned with laying out a menu of arguments to defend the importance of social policy, particularly in health, and also with the relevance of his presence and his interventions in these discussion forums. His discourse sought to garner support among different audiences by asserting, in his style and in this context, a rationale that required recognition of the ties between health, illness, and productivity (to cite only a few of the broad gamut of possibilities), without relinquishing the "humanistic" facet so dear to the sanitary tradition. Mediating between development, as a public philosophy, and a programmatic sectoral agenda also meant producing enunciations that breathed new life into traditional elements from the perspective of a new framework of values.

Horwitz displays notable caution when it comes to the most controversial topics of debate in the realm of economics and social reforms, and he steadily distances himself from these. He takes no patently clear position on industrialization and therefore does not venture into a theme especially cherished by Latin America's most economically complex and politically ambitious countries. He virtually omits the issue of fiscal and agrarian reform at a time when these issues were most certainly not of great interest to the Latin American elites, but when they joined the list of measures defended by the United States' ambiguous but not paradoxical policy, which pragmatically tipped its hat to socioeconomic reform, democracy, and reactionary conspiracy alike.

Horwitz wholly embraced the "civilizing" intent of development but in his discourse he placed greater emphasis on less controversial themes on the development agenda. Among these stood basic education, housing, scientific and technological cooperation, planning, and, of course, health - in other words, a set of issues more fitting to what were considered eminently technical approaches and thus perhaps constituting a more comfortable array for an intergovernmental, sectoral organization like PAHO. So when Horwitz settled on a less divisive set of development themes, he perhaps wanted to lay the broadest basis possible for agile institutional engagement, in the guise of technical neutrality.

Horwitz's discursive choices may also account for the absence of any direct mention of the issue of democracy. While he did not shun an economic or productivist bias in dealing with matters of health, he did underscore an essentially human dimension as reason enough for attention to health. He also asserted that adequate economic and social conditions were vital if men and women were to fully realize their potential in the most diverse spheres of activity. However, he avoided the themes of political and economic liberties, democracy, and so-called Western values. This coincided with some of the hottest days of the Cold War, when the Cuban question was at the fore, and when social, and therefore, health policies had caught the attention of those concerned with blocking the advance of socialist movements in the Americas; it was also a time when these social themes acquired an undeniable strategic content as part and parcel of security concerns.

If Horwitz took advantage of the fact that health now enjoyed a new place on the agenda, he did so while avoiding any direct participation in the most controversial disputes and likewise dealing with the proposed development agenda selectively. Once again, he worked to safeguard his intended neutrality by defending a more consensual agenda. It was perhaps this option and Horwitz's faithfulness to this path that made it possible, for instance, for 
Cuba to remain on as a full member of PAHO at the end of the day, even after it was kicked out of the OAS in 1962.

These discursive choices and their implications in the more concrete realm of institutional policy shed light on the means by which general values and principles were (or were not) brought to bear within the dynamics of development when decisions were made about conflicts and choices, according to the logic of one agent. They suggest to us how this case of sectoral mediation involved an effort to identify the most attractive themes and help place them on the programmatic agenda, in keeping with a given institutional rationale projected into the future, one which could not forsake values and principles dear to the tradition of public health and to its self-image as a civilizing endeavor.

\section{AKNOWLEDGEMENT}

This paper has been partially elaborated as part of the project "Health and International Relations: foreign policy and international cooperation on health issues", supported by Fundação Carlos Chagas Filho de Amparo à Pesquisa do Estado do Rio de Janeiro, Research Support Foundation of the State of Rio de Janeiro, Brazil.

\section{NOTES}

${ }^{1}$ Born in Chile and educated as a physician, Abraham Horwitz (1910-2000) was a noteworthy figure in
inter-American health in the latter half of the twentieth century. He was a specialist in infectious contagious
disease and public health and played an important part in establishing Chile's School of Public Health and its
National Health Service. He was the first Latin American director of PAHO during one of the most dynamic
periods in the history of the institution, from 1958 to 1975 . See Cueto (2007) and Jimenez De La Jara (2003).
${ }^{2}$ Within the framework of Point IV, launched by the United States in 1949, the 1950s signaled the beginning
of development efforts in the post-World War II era. However, the real reach of development was limited
during this period, and some analysts regard the decade as a time of institutional maturation for the
development paradigm (Rist, 2002, chap.4). A brief overview of the genesis and development of Point IV
can be found in Paterson (1973). The United States and Latin American countries entered into a number
of bilateral agreements during this time, some of which encompassed health. One example would be the
agreements with Brazil, which partially sustained the Special Public Health Service (Serviço Especial de Saúde
Pública, Sesp). For a history of Sesp, see Campos (2006). The resources invested in these initiatives and their
importance trended downward over the course of the decade.

${ }^{3}$ This possibility becomes more obvious when we consider analyses from the field of political science
that endeavor to ascribe (or re-ascribe) a main role to the State as a social actor. For a critical review of the
literature on the role of the State as a social actor, such as those produced by neo-Marxist analysis, historical
institutionalism, sectoral analysis, or state in society approaches, see Eduardo Marques (1997).

${ }^{4}$ Fonseca's (2007) presentation and use of Weir's propositions were of great value to us.

${ }^{5}$ Functional international organizations are dedicated to specialized fields, such as health, labor, nuclear energy, and education, science, and culture. For a classification of international organizations, see Herz and Hoffmann (2004, especially chap.1).

${ }^{6}$ The heyday of the philosophy of development can be more precisely situated as dating from the launching of the Truman administration's Point IV, in 1949, to the second oil crunch, in 1979. Although the term still appears in speeches and in the titles of initiatives, the ideological significance and the very strength of development was heavily eroded by the foreign debt crisis, the 1980s recession, and the neoliberal offensive.

${ }^{7}$ Escobar is a Colombian anthropologist who resides in the United States, where he teaches at the University of North Carolina at Chapel Hill. His research explores the anthropology of development and of Colombian, Latin American, and anti-globalization social movements, among other topics. For the purpose of the citations in this paper, we have used the Spanish edition for Latin America (Escobar, 1998).

${ }^{8}$ Some of these critics find it problematic to tie the source of development as a regime of power and knowledge to a notion as imprecise as "the West" (Cooper, Packard, 1997, p.3). Others disagree with the 
"post-developmentalist" political agenda, which inspired work like Escobar's. For an assessment of this debate, see Edelman and Haugerud (2005a) and, in Portuguese, Andrade (2012).

${ }^{9}$ Escobar (1998, p.22-23) explicitly states that dependency theory, alongside the pedagogy of the oppressed and liberation theology, are components of a 1960s and 1970s critique of development, which wielded a positive influence over post-modernist critique in the 1980s and 1990s.

${ }^{10}$ A native of Switzerland, Gilbert Rist is currently a professor at the Institut Universitaire d'Etudes du Développement in Geneva. A summarized version of his main arguments can be found in Rist (2006).

${ }^{11}$ The Committee of 21 held meetings in Washington (nov.-dec. 1958), in Buenos Aires (apr.-may 1959), and in Bogota (sept. 1960). See Silva (2011).

12 The motivation for this change was a growing concern with the penetration of communist ideas and with communist mobilization in developing countries. Its point of departure was the Soviets' mid-decade intensification of their economic offensive in trade and cooperation. Analysts hold divergent opinions about the relevance of these early events, but there is a consensus about the weight and impact of the Cuban Revolution and the anti-American hostility that was exhibited during vice-president Richard Nixon's visit to a number of Latin American countries. For a critical evaluation of these analyses, see Sewell (2008).

${ }^{13}$ In this and other citations of texts from non-English languages, a free translation has been provided.

${ }^{14}$ Although the topic of health was not included in the original formulation of Operation Pan America (June 1958), it is found on the agenda of the Committee of 21 as of its second meeting, in 1959 (Horwitz, 1959). To judge from Jornal do Brasil's coverage of the preparatory meetings for the 1960 meeting in Bogota (which produced the act), this topic did not mobilize Brazilian authorities or the country's press, which made mention only of economic and land use issues (primarily) and of literacy. The make-up of the Brazilian delegation's advisory group at the preparatory events and at the meeting itself is indicative of this; it included diplomats, economists (Roberto Campos, Cleantho de Paiva Leite, and Luis Carlos Mancini), and one educator (Anísio Teixeira) but no expert in medicine or public health. See, for example, Comitê... (5 jun. 1960, p.5).

${ }^{15}$ Cuba was the only country that did not sign the meeting's closing documents. Its stance was always one of radical opposition to the principles that governed the proposal's original formulation, principles that Cuba felt were meant to sustain US hegemony in the region and were heavily assistentialist in nature. An especially noteworthy passage is found in one of the speeches by Guevara, head of the Cuban delegation in Punta del Este, where he underscores the importance of industrialization to the development process and criticizes the US proposal, stressing that in this case, "the matter of industrialization is not part of the analysis of the experts. For the experts, planning means planning a latrine. And the other issues, who knows when they will be addressed?" (Guevara, cited by Botega, 2009, p.158).

${ }^{16}$ This tension between the US vision and that of Latin American nations, with Brazilian diplomacy playing a leading role, had been plain ever since Juscelino Kubitschek proposed Operation Pan America. See, for example, Alves (18 set. 1960).

${ }^{17}$ The two articles are "El desarrollo económico y el bienestar social" (Horwitz, 1961c) and "Planificación del desarrollo económico y social en la América Latina" (Horwitz, 1961b).

${ }^{18}$ On health and wealth was originally published under the title "O papel da Organização Pan-Americana da Saúde no Programa de Desenvolvimento da OEA" as an article in the journal Américas, the monthly periodical of the Pan American Union, which was the name of the OAS secretariat until 1970, when it was changed to General Secretariat of the Organization of American States. See Horwitz (1960a).

${ }^{19}$ Charles-Edward A. Winslow was professor of public health at Yale University from 1915 to 1945 . He served as editor of a number of publications and wrote articles in the fields of bacteriology and public health. He was also president of the American Public Health Association. He wrote the monograph The cost of sickness and the price of health, published by WHO in 1951; it was translated into Spanish and published by PAHO in 1955. Gunnar Myrdal was a Swiss-born economist and, at the time, president of the United Nations Economic Commission for Europe. He did important work in areas like race relations, poverty, and international economics and was one of the top names in the intellectual and political debate on development. He received the Nobel Prize in Economics in 1974.

${ }^{20}$ Here Horwitz relies on the work of René Sand, a Belgian physician with a relevant background in the fields of European social medicine and social service after the 1914-1918 war.

${ }^{21}$ Alberto Baltra Cortés, an attorney with advanced studies in economics, was professor of economics at the School of Law and Social Sciences, Universidad de Chile, and also minister of the Economy. He was the 
first president of ECLA and later served as its advisor. In the 1960s, he was senator for the Partido Radical; in 1969, he threw his hat in the ring as a presidential candidate but later pulled out in support of Salvador Allende. See Baltra Cortés (1969, 1959).

22 The works of Thomas McKeown, US physician and historian, comprise articles and books published from 1955 to 1978; based on historical and demographic arguments, he sought to prove that advances in housing and in the production and distribution of food played a determinant role in improving health conditions and, further, that sanitary practices and even any decrease in the virulence of major pathogenic agents were of secondary importance. Some historians suggest that his work wielded more influence and stirred greater controversy in the 1970s and 1980s, even after its empirical basis had been refuted. Horwitz's reliance on this line of argument may indicate that the article "Medical evidence related to English population changes in the eighteenth century" (McKeown, Brown, 1955) still had a substantial impact in the latter half of the 1950s, when social policy themes enjoyed a greater presence. For an overview of the debates on McKeown's thesis, see Colgrove (2002).

${ }^{23}$ For further information on the emergence of this field in global and inter-American contexts, see PiresAlves, Paiva, and Hochman (2008).

${ }^{24}$ Cuba, as we saw, was not part of this relative consensus but tended to assume more isolated stances, in response either to US initiatives to impose constraints on the new Cuban government, to the growing entrenchment of that country's revolutionary process, or to the strong prevalence among Latin America's leading elites of pro-Western, anti-communist positions.

\section{REFERENCES}

ALVES, Hermano.

OPA em Bogotá: compromisso dos EUA e vitória do Brasil. Jornal do Brasil, p.8. 18 set. 1960.

ANDRADE, Rômulo de Paula.

A Amazônia na era do desenvolvimento: saúde, alimentação e meio ambiente (1946-1966). Tese (Doutorado em História das Ciências e da Saúde) - Casa de Oswaldo Cruz, Fundação Oswaldo Cruz. Rio de Janeiro. 2012.

BALTRA CORTÉS, Alberto.

América Latina y la segunda UNCTAD. Estudios Internacionales, v.2, n.4, p.449-460. 1969.

BALTRA CORTÉS, Alberto.

Crecimiento económico de América Latina: problemas fundamentais. Santiago: Editoria del Pacífico. 1959.

BIELSCHOWSKY, Ricardo.

Evolución de las ideas de la Cepal. Revista Cepal, número extraordinário, p.21-45. out. 1998. Disponível em: http://www.cepal.org/ publicaciones/xml/3/19373/bielchow.htm. 1998.

BOTEGA, Leonardo da Rocha.

Brasil, Argentina e a questão cubana (1959-1964): quando a independência faz a união. Dissertação (Mestrado em Integração Latino-Americana) - Universidade Federal de Santa Maria, Santa Maria, RS. 2009.

CAMPOS, André Luiz Vieira de.

Políticas internacionais de saúde na Era Vargas: o Serviço Especial de Saúde Pública, 1942-1960. Rio de Janeiro: Editora Fiocruz. 2006.
COLGROVE, James.

The McKeown thesis: a historical controversy and its enduring influence. American Journal of Public Health, v.92, n.5, p.725-729. 2002.

COMITÊ...

Comitê dos 9 começa a planejar amanhã desenvolvimento econômico da América Latina. Jornal do Brasil. Primeiro caderno, p.5. 5 jun. 1960.

COOPER, Frederick; PACKARD, Randall.

Introduction. Cooper, Frederick; Packard, Randall (Ed.). International development and the social sciences: essays on the history and politics of knowledge. Berkeley: University of California Press. 1997.

CUETO, Marcos.

O valor da saúde: história da Organização Panamericana da Saúde. Rio de Janeiro: Editora Fiocruz. 2007.

EDELMAN, Marc; HAUGERUD, Angelique. The anthropology of development and globalization: from classical political economy to contemporary Neoliberalism. Malden, MA: Blackwell. 2005a.

EDELMAN, Marc; HAUGERUD, Angelique. Introduction: the anthropolgy of development and globalization. In: Edelman, Marc; Haugerud, Angelique. The anthropology of development and globalization: from classical political economy to contemporary neoliberalism. Malden, MA: Blackwell. 2005b.

ESCOBAR, Arturo.

La invención del Tercer Mundo: construción e 
desconstrución del desarrollo. Santafé de Bogotá: Grupo Editorial Norma. 1998.

ESCOBAR, Arturo.

Encountering development: the making and unmaking of the Third World. Princeton: Princeton University Press. 1995.

FINNEMORE, Martha.

National interests in international society. Ithaca: Cornell University Press. 1996.

FONSECA, Cristina Maria Oliveira.

Saúde no governo Vargas: dualidade institucional de um bem público. Rio de Janeiro: Editora Fiocruz. 2007.

HERZ, Mônica; HOFFMANN, Andrea Ribeiro R. Organizações internacionais: história e práticas. Rio de Janeiro: Elsevier. 2004.

HORWITZ, Abraham.

Reflexiones sobre economia y salud. Boletín de la Oficina Sanitaria Panamericana, v.51, n.2, ago. 1961, p.97-103. 1961a.

HORWITZ, Abraham.

Planificación del desarrollo económico y social em América Latina. Boletín de la Oficina Sanitaria Panamericana, v.51, n.5, nov. 1961, p.379-386. 1961b.

HORWITZ, Abraham.

El desarrollo economico y el bienestar social. Boletín de la Oficina Sanitaria Panamericana, v. 51, n.5, nov. 1961, p.387-389. 1961c.

HORWITZ, Abraham.

A saúde e a riqueza. Washington: Organização Pan-americana da Saúde. 1960a.

HORWITZ, Abraham.

Programas de salud como componentes del desarrollo económico en las Americas. Boletín de la Oficina Sanitaria Panamericana, v.49, n.5, nov. 1960, p.403-409. 1960b.

HORWITZ, Abraham.

Relaciones entre salud y desarrollo econômico. Boletín de la Oficina Sanitaria Panamericana, v.47, n.2, ago. 1959, p.93-100. 1959.

ISH-SHALOM, Piki.

Theory gets real, and the case for a normative ethic: Rostow, Modernization Theory, and the Alliance for Progress. International Studies Quarterly, n.50, p.287-311. 2006.

JIMENEZ DE LA JARA, Jorge.

Abraham Horwitz (1910-2000): padre de la salud pública panamericana. Revista Médica de Chile, v.131, n.8, p.929-934. 2003.

KENNEDY, John Fitzgerald.

Address at a White House reception for members of Congress and for the diplomatic corps of the
Latin American republics. Washington. 1961. Disponível em: http://www.jfklibrary.org/AssetViewer/Archives/JFKPOF-034-013.aspx. Acesso em: 1 nov. 2010. 13 mar. 1961.

MAIO, Marcos Chor et al.

Cooperação internacional e políticas de ação afirmativa: o papel da Organização PanAmericana da Saúde (Opas). Cadernos de Saúde Pública, v.26, n.7, p.1273-1291. 2010.

MARQUES, Eduardo.

Notas críticas à literatura sobre Estado, políticas estatais e atores políticos. Revista Brasileira de Informação Bibliográfica em Ciências Sociais, n.43, p.3-156. 1997.

MCKEOWN, Thomas; BROWN, R.G.

Medical evidence related to English population changes in the eighteenth century. Population Studies, n.9, p.119-141. 1955.

MYRDAL, Gunnar.

Economic aspects of health. Chronicle of the World Health Organization, v.6, n.7-8, p.203-218. 1952.

OEA.

Organização dos Estados Americanos.

Declaración a los Pueblos de América. Carta de Punta del Este, Plano Decenal de Educación (anexo I) e Plano Decenal de Salud Pública de la Aliança para el Progresso (anexo II). (Documentos finais da Reunião Extraordinária do Conselho Interamericano Econômico e Social em Nível Ministerial. Punta del Este, ago. 1961). Colômbia - Ministerio de Hacienda y Crédito Público. El Programa de la Alianza para el Progreso. 1961. Disponível em: http://www. bdigital.unal.edu.co/11962/13/Primera\%20 Parte\%20-\%20El\%20programa\%20de\%20la\%20 alianza\%20para\%20el\%20progreso.pdf. 1961.

OEA.

Organização dos Estados Americanos. Ata de Bogotá. Washington. 13 set. 1960.

OPAS.

Organização Pan-americana de Saúde. Hechos sobre problemas de salud: la salud en relación con el progreso social y el desarrollo económico en las Américas (OSP. Publicaciones Varias, 63). Washington: Oficina Sanitaria Panamericana. 1961.

PATERSON, Thomas G.

Foreign aid under wraps: the Point Four Program. The Wisconsin Magazine of History, v.56, n.2, p.119-126. 1973.

PIRES-ALVES, Fernando A.; PAIVA, Carlos Henrique Assunção; HOCHMAN, Gilberto. História, saúde e seus trabalhadores: da agenda internacional às políticas brasileiras. Ciência e Saúde Coletiva, v.13, n.3, p.819-829. 2008. 
RIBEIRO, Ricardo Alaggio.

A Aliança para o Progresso e as relações Brasil$E U A$. Tese (Doutorado em Ciência Política) Universidade Estadual de Campinas, Instituto de Filosofia e Ciências Humanas, Campinas. 2006.

RIST, Gilbert.

Before thinking about What Next: prerequisistes for alternatives. Development Dialogue, n.47, jun. 2006, What Next, v.1, Setting the context, p.65-95. 2006.

RIST, Gilbert.

The history of development: from Western origins to global faith. London; New York: Zed Books. 2002.

RIVERA, Francisco Javier Uribe; ARTMANN, Elizabeth.

Planejamento e gestão em saúde: conceitos, história e propostas. Rio de Janeiro: Editora Fiocruz. 2012.

SEWELL, Bevan.

A perfect (free-market) world? Economics, the Eisenhower administration, and the Soviet economic offensive in Latin America. Diplomatic History, v.32, n.5, p.841-868. 2008.

SILVA, Alexandra de Mello e. A política extema de JK: a Operação PanAmericana. Rio de Janeiro: CPDOC. 1992.
SILVA, Marcela Camila Bracher.

De Rostow a Cepal: as ideias de desenvolvimento na configuração do Explicit Democratic Approach do Governo Kennedy na América Latina. In: Simpósio de Pós-Graduação em Relações Internacionais do Programa San Tiago Dantas, 3., 8-11 nov. 2011, São Paulo. Anais... São Paulo: Programa de Pós-graduação em Relações Internacionais San Tiago Dantas (Unesp, Unicamp e PUC-SP). Disponível em: http://www.santiagodantassp.locaweb.com.br/br/ simp/artigos2011/marcela_silva.pdf. 2011.

WEIR, Margaret.

Ideas and the Politics of Bounded innovation. Steinmo, Sven; Thelen, Kathleen; Longstreth, Frank (Ed.). Structuring Politics: historical institutionalism in comparative analysis. Cambridge: Cambridge University Press. 1992.

WINSLOW, Charles-Edward Armory.

The economic values of preventive medicine. Chronicle of the World Health Organization, v.6, n.7-8, p.191-202. 1952.

WINSLOW, Charles-Edward Armory.

The cost of sickness and the price of health.

Genebra: World Health Organization. 1951.

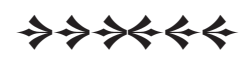

